\title{
HIDROLOŠKE RAZISKAVE ARSO NA OBMOČJU BOHINJA
}

\author{
Marjan Bat \\ Sektor za hidrologijo Urada za monitoring ARSO, Vojkova Ib, \\ SI- I000 Ljubljana, Slovenija \\ e-mail: marjan.bat@gov.si
}

Izvirni znanstveni članek

COBISS 1.01

\section{Izvleček}

Na sektorju za hidrologijo Agencije Republike Slovenije za okolje (ARSO) na območju Bohinja izvajamo opazovanja na Savici v Ukancu, na Mostnici v Stari Fužini, na Savi Bohinjki pri Svetem Janezu, na Bistrici v Bohinjski Bistrici ter na Bohinjskem jezeru pri Svetem Duhu. Podatke meritev preverjamo in usklajujemo z meteorološkimi pri vodni bilanci. V podporo našim rednim meritvam izvajamo tudi sledilne poskuse. Dva, ki smo ju izvedli na območju Bohinja, sta skupaj z rezultati bilance potrdila, da vodozbirnih zaledij tukajšnjih v.p. ne moremo obravnavati ločeno.

Ključne besede: vodomerna postaja, vodostaj, temperatura vode, pretok, podatkovni niz, sledilni poskus, vodna bilanca, Slovenija, Bohinj, Bohinjsko jezero.

\section{HYDROLOGICAL INVESTIGATIONS OF ARSO IN THE BOHINJ REGION}

\begin{abstract}
The Environmental Agency of the Republic of Slovenia (ARSO) performs hydrological measurements in the Bohinj region at the water gauging stations on the Sava Bohinjka, the Savica, the Bistrica, the Mostnica, and on Lake Bohinj. The summarized results of the observations are regularly published in Hydrological Yearbooks and are available to public. Within the water balance analyses the data on water discharges are harmonized with the data on precipitation and evapotranspiration. Two water tracing tests were made in the Bohinj region in order to clear up the established discordances. They show that, due to karstic bifurcation, the drainage area of the water gauging stations in the Bohinj region has to be treated as one unit as far as the water balance is concerned.
\end{abstract}

Key words: water gauging station, water level, water temperature, discharge, data set, water tracing test, water balance, Slovenia, Lake Bohinj, Bohinj. 


\section{UVOD}

Po programu državnega monitoringa voda opravljamo na sektorju za hidrologijo ARSO na območju Bohinja redna opazovanja na vodomernih postajah (v.p.) Ukanc na Savici, Stara Fužina II na Mostnici, Sveti Janez na Savi Bohinjki, Bohinjska Bistrica na Bistrici ter Sveti Duh na Bohinjskem jezeru. Večino zbranih podatkov delujočih in opuščenih merilnih mest hranimo $\mathrm{v}$ elektronskih podatkovnih zbirkah, manjši del v klasičnem arhivu (Arhiv in podatkovne baze...2007). Žal je del najstarejših podatkov najbrž izgubljen ali pa so ohranjeni le v fragmentih. Vsi podatki naših podatkovnih zbirk od poročil opazovalcev, limnigrafskih trakov, obdelanih podatkov, pretočnih krivulj itd. so na voljo za študijske in raziskovalne namene. Po digitalizaciji gradivo v klasični obliki postopno predajamo Arhivu RS. Zainteresirano javnost zaenkrat o rezultatih meritev obveščamo le s povzetki, objavljenimi v Hidroloških letopisih.

Preglednica 1: Seznam delujočih in opuščenih v.p. na območju Bohinja ter njihovi podatkovni nizi v elektronski obliki.

Table 1: The list of active and abandoned water gauging station in the Bohinj region with digital data series.

\begin{tabular}{|c|c|c|c|c|c|c|c|c|c|}
\hline \multirow[t]{3}{*}{$\begin{array}{l}\text { Šifra/ } \\
\text { code }\end{array}$} & \multirow[t]{3}{*}{$\begin{array}{l}\text { VODOTOK/ } \\
\text { stream }\end{array}$} & \multirow[t]{3}{*}{$\begin{array}{l}\text { Vodomerna } \\
\text { postaja/gauging } \\
\text { station }\end{array}$} & \multirow{3}{*}{$\begin{array}{c}\text { Površina } \\
\text { vodozbirnega } \\
\text { zaledja/ } \\
\text { drainage area } \\
\mathrm{km}^{2}\end{array}$} & \multicolumn{2}{|c|}{$\begin{array}{l}\text { Deluje/ } \\
\text { active }\end{array}$} & \multirow[t]{2}{*}{$\begin{array}{l}\text { Tip/ } \\
\text { equip- } \\
\text { ment }\end{array}$} & \multirow[t]{2}{*}{$\begin{array}{l}\text { Veli- } \\
\text { čina/ } \\
\text { para- } \\
\text { meter }\end{array}$} & \multicolumn{2}{|c|}{$\begin{array}{c}\text { Elektronski } \\
\text { podatkovni } \\
\text { niz/digital } \\
\text { data series }\end{array}$} \\
\hline & & & & $\begin{array}{c}\mathrm{Od} / \\
\text { since }\end{array}$ & $\begin{array}{c}\mathrm{Do} / \\
\text { to }\end{array}$ & & & $\begin{array}{c}\mathrm{Od} / \\
\text { since }\end{array}$ & $\begin{array}{c}\mathrm{Do} / \\
\text { to }\end{array}$ \\
\hline & & & & \multicolumn{2}{|c|}{ leto / year } & & & leto & year \\
\hline 3200 & Sava Bohinjka & Sveti Janez & 93,99 & 1951 & & $\mathrm{~L}$ & $\mathrm{H}, \mathrm{Q}$ & 1959 & 2004 \\
\hline $3210 / 20$ & Sava Bohinjka & Soteska & 288,19 & 1926 & 1989 & $\mathrm{O}, \mathrm{L}$ & $\mathrm{H}, \mathrm{Q}$ & 1951 & 1989 \\
\hline 3260 & Savica & Ukanc & 66,71 & 1951 & & $\mathrm{O}, \mathrm{L}, \mathrm{P}$ & $\mathrm{H}, \mathrm{Q}, \mathrm{T}$ & 1951 & 2004 \\
\hline 3280 & Bohinjsko j. & Sveti duh & 93,99 & 1905 & & $\mathrm{O}, \mathrm{P}$ & $\mathrm{H}, \mathrm{T}$ & 1919 & 2004 \\
\hline 3285 & Mostnica & Stara fužina I & 41,11 & 1951 & 1966 & $\mathrm{O}$ & $\mathrm{H}, \mathrm{Q}$ & 1951 & 1966 \\
\hline 3290 & Mostnica & Stara fužina & 74,26 & 1910 & 1958 & $\mathrm{O}$ & $\mathrm{H}, \mathrm{Q}$ & 1951 & 1958 \\
\hline 3300 & Mostnica & Stara fužina II & 74,26 & 1959 & & $\mathrm{O}, \mathrm{P}$ & H, Q & 1959 & 2004 \\
\hline 3320 & Bistrica & Bohinjska Bistrica & $\begin{array}{r}\text { ni podatka/ } \\
\text { no data }\end{array}$ & 1968 & & $\mathrm{O}, \mathrm{L}$ & $\mathrm{H}, \mathrm{Q}$ & 1968 & 2004 \\
\hline 3330 & Predorski potok & Bohinjska Bistrica & $\begin{array}{r}\text { ni podatka/ } \\
\text { no data }\end{array}$ & 1965 & 1971 & $\mathrm{~L}$ & $\mathrm{H}, \mathrm{Q}$ & 1965 & 1971 \\
\hline
\end{tabular}

\section{Pojasnila/Explanations:}

Delujelactive: leto je določeno po zapisu v temeljni knjigi vodomerne postaje ali pa je usklajeno s podatki $v$ arhivu sektorja za hidrologijo/upon the records in archives

Tiplequipment: $O$-opazovanja oz. vodomer/observations -staffgauge, $L$-limnigraf/water level recorder, $P$ - podatkovni zapisovalnik/data logger

Veličine/parameter: $H$ - vodostaj/water level; $Q$ - pretok/discharge; $T$ - temperatura vode/water temperature. 
Zaradi obravnave voda kot pokrajinskega elementa navajamo tudi delujoče v.p., katerih vodozbirna zaledja mejijo na območje Bohinja.

Preglednica 2: Delujoče v.p., katerih vodozbirna zaledja mejijo na območje Bohinja.

Table 2: The list of active gauging stations with drainage basin adjacent on the Bohinj region.

\begin{tabular}{|l|l|l|c|c|c|}
\hline $\begin{array}{l}\text { Šifra/ } \\
\text { code }\end{array}$ & VODOTOK/stream & $\begin{array}{l}\text { Vodomerna postaja/ } \\
\text { gauging station }\end{array}$ & $\begin{array}{c}\text { Površina vodozbirnega } \\
\text { zaledja/drainage area }\end{array}$ & $\begin{array}{c}\text { Deluje od/ } \\
\text { active since }\end{array}$ & $\begin{array}{c}\text { Tip/ } \\
\text { equipment }\end{array}$ \\
\hline 3250 & Sava Bohinjka & Bodešče & 363,91 & leto /year & L \\
\hline 3015 & Sava Dolinjka & Kranjska gora & 44,98 & 1990 & $\mathrm{O}$ \\
\hline 3060 & Sava Dolinjka & Jesenica & 257,56 & 1918 & $\mathrm{~L}$ \\
\hline 3080 & Sava Dolinjka & Blejski most & 505,40 & 1959 & $\mathrm{~L}$ \\
\hline 3180 & Radovna & Podhom & 166,79 & 1933 & $\mathrm{~L}$ \\
\hline 3400 & Jezernica & Mlino I & 8,61 & 1955 & $\mathrm{O}$ \\
\hline $3410 / 20$ & Sava & Radovljica I* & 907,97 & 1913 & $\mathrm{D}$ \\
\hline 4270 & Selška Sora & Železniki & 104,10 & 1991 & $\mathrm{~L}$ \\
\hline $8030 / 31$ & Soča & Kršovec I & 158,05 & 1954 & $\mathrm{~L}$ \\
\hline 8060 & Soča & Log Čezsoški $*$ & 324,74 & 1928 & $\mathrm{~L}$ \\
\hline 8080 & Soča & Kobarid I & 437,02 & 1928 & $\mathrm{~L}, \mathrm{D}$ \\
\hline 8330 & Tolminka & Tolmin & 73,08 & 1953 & $\mathrm{~L}$ \\
\hline 8500 & Bača & Bača pri Modreju & 142,31 & 1940 & $\mathrm{~L}$ \\
\hline
\end{tabular}

* Avtomatska merilna postaja/automatic gauging station Tip/equipment: $O$ = opazovanjelobservations; $L=$ limnigraf/water level recorder, $D=$ podatkovni zapisovalnik/data logger

Slika 1: Vodozbirno zaledje Save Bohinjke gorvodno od Soteske z lokacijami vodomernih postaj (• delujoče; • opuščene) na območju Bohinja.

Figure 1: The drainage basin of the Sava Bohinjka River upstream of the Soteska with the locations of the gauging stations (• active; • abandoned) in the Bohinj region.

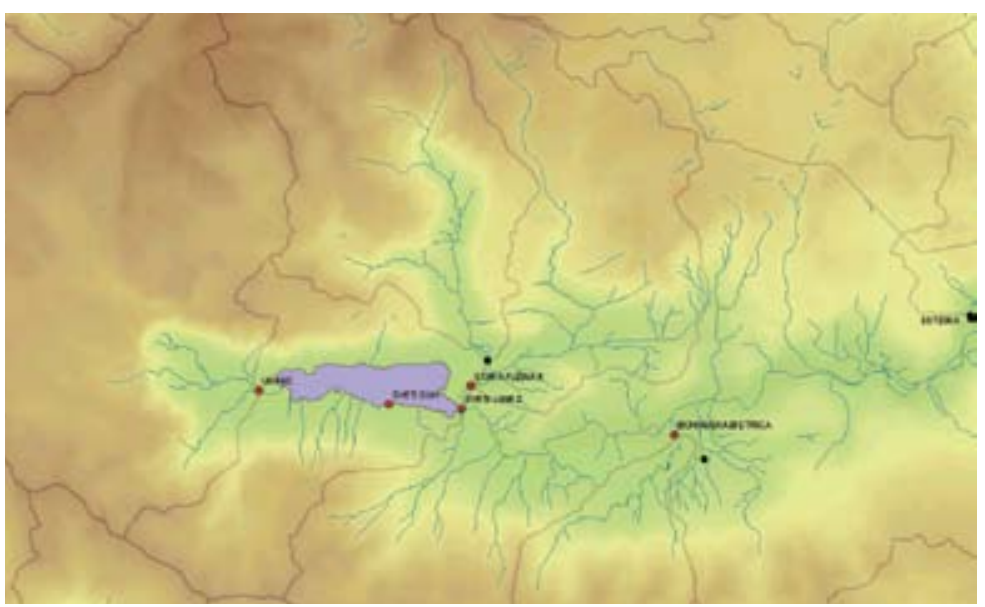




\section{VODOSTAJI}

Vodostaji so osnovna veličina, ki jo merimo na vseh vodomernih postajah državnega monitoringa voda. Pri obravnavi jezer so bistvenega pomena, medtem ko so pri rekah predvsem namenjeni določanju pretokov. Ti so medsebojno laže primerljivi in imajo večjo informacijsko vrednost.

Za Bohinjsko jezero imamo enega daljših nizov vodostajev v Sloveniji. Z redkimi prekinitvami sega vse do leta 1919 - manjka le leto 1929 in trije meseci v letu 1996. Letni režim nihanja gladine Bohinjskega jezera (Slika 2) je bil prikazan za tridesetletne nize podatkov in je znan (Radinja 1987, 302; Bat 2003). Po obliki se sklada z alpskim snežno-dežnim pretočnim režimom rek na območju Julijskih Alp (Frantar 2005).

Slika 2: Povprečne mesečne srednje (sHs), nizke (sHnp) in visoke (sHvp) gladine Bohinjskega jezera za obdobje 1919-2004.

Figure 2: The average monthly mean (sHs), low (sHnp) and high (sHvp) water levels of Lake Bohinj for the 1919-2004 period.

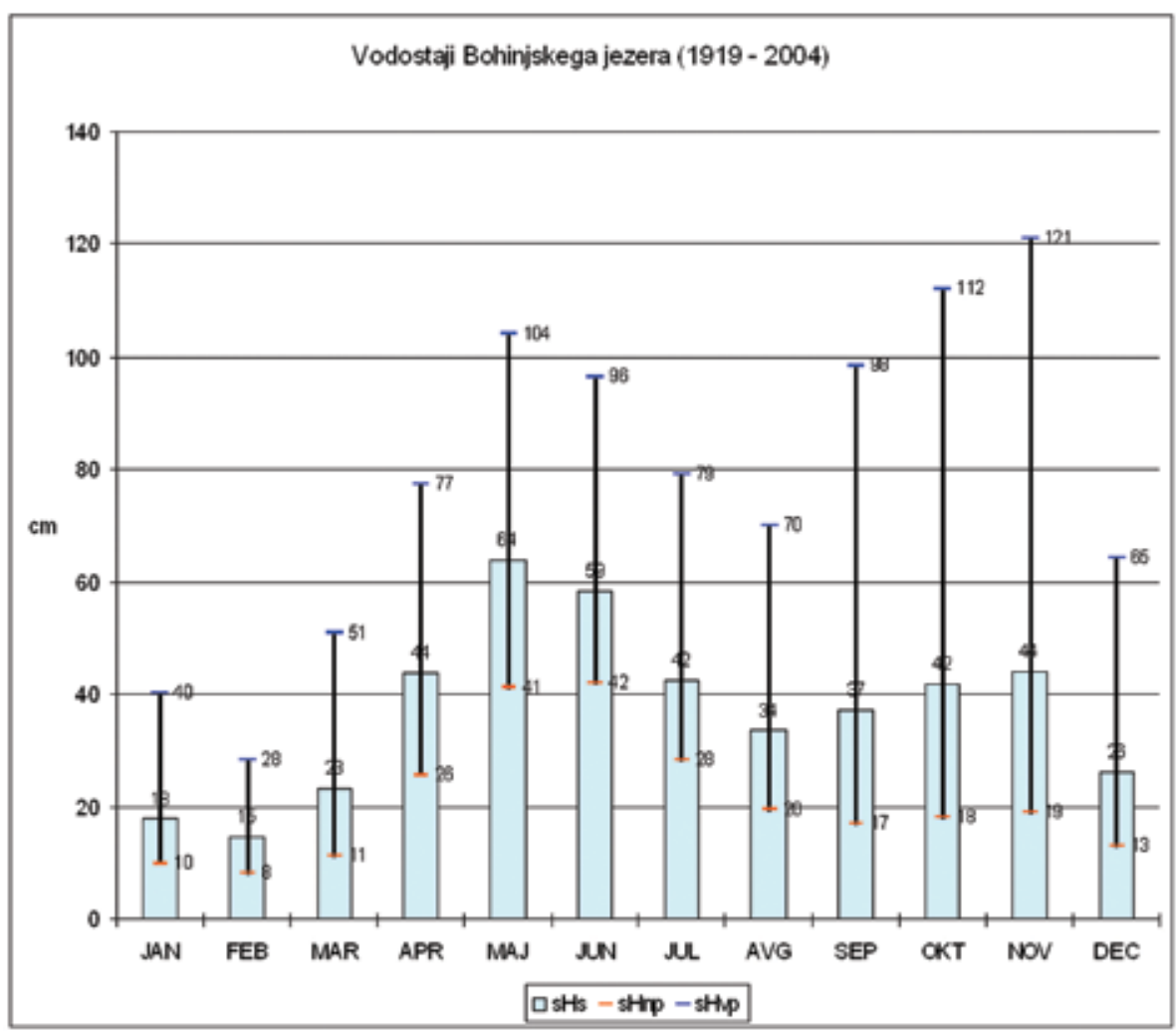


Iz celotnega niza pa lahko razberemo še nekatere poteze, ki jih pri analizi tridesetletnega ne moremo zaznati. Če si ogledamo spreminjanje gladine prek leta po desetletjih vidimo, da je le v obdobju 1991-2000 (velja tudi za niz 1991-2004) jesenski višek oktobra skoraj izenačen z majskim, ob upoštevanju drugega pomladnega (junij) oz. jesenskega (november) meseca pa ga celo preseže (Slika 4). Ta poteza je v okviru celotnega opazovanega obdobja nekaj izjemnega. Ob krajših nizih je bila dokumentirana pri pretočnih režimih (Frantar 2003) in torej ni posebnost Bohinjskega jezera. V primerjavi tridesetletnih nizov (od 1921-1950 do 1971-2000) je pri nizu 1971-2000 krepitev jesenskega viška nakazana, prvič pa obdobni oktobrski srednji vodostaj (sHs) preseže novembrskega (Slika 3).

Sliki 3 in 4: Srednje mesečne gladine (sHs) Bohinjskega jezera za 30-in 10-letne nize od 1921 do 2000 .

Figure 3 and 4: The mean monthly water levels (sHs) of Lake Bohinj for the 30- and 10-year series in the 1921-2000 period.

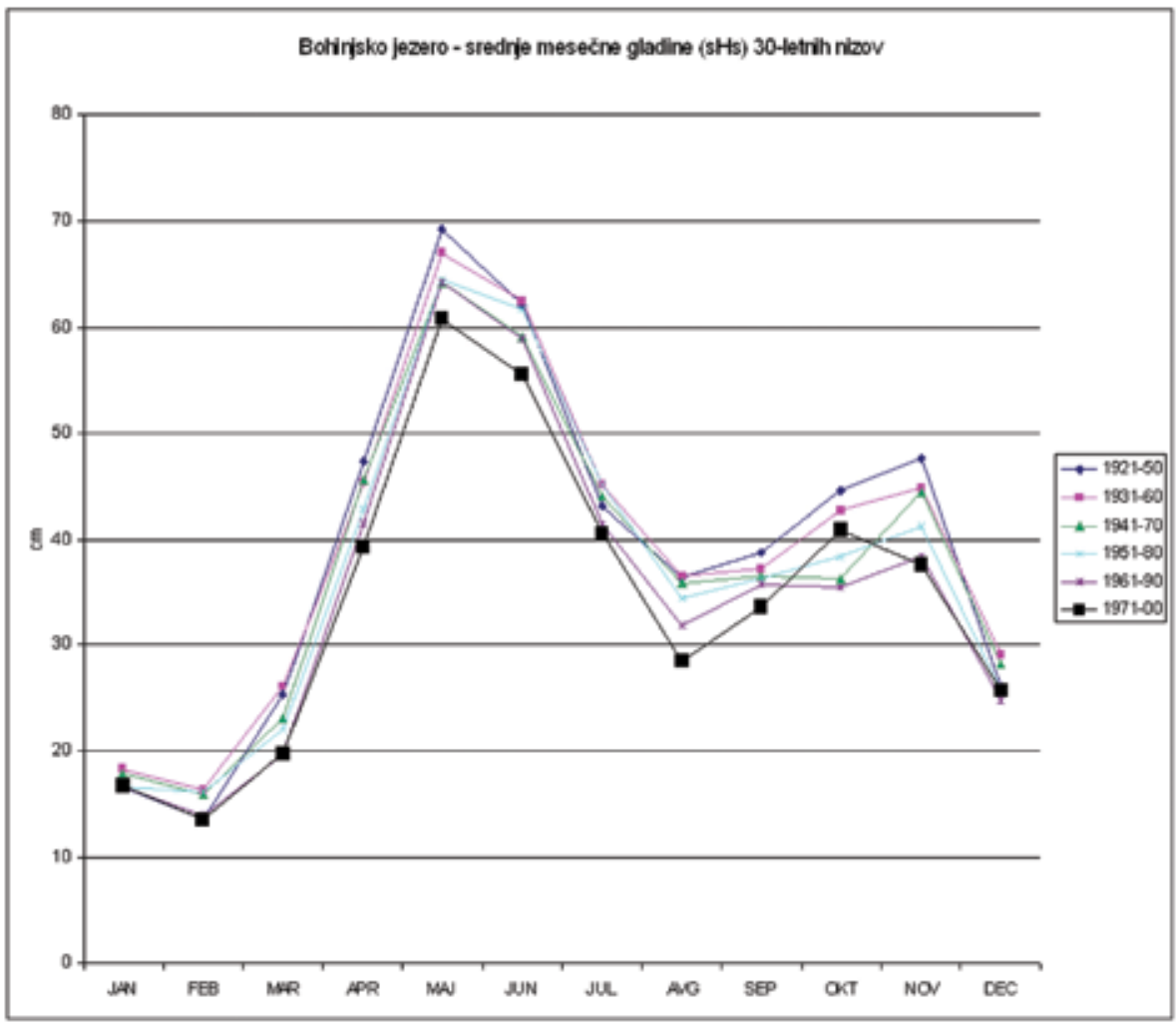




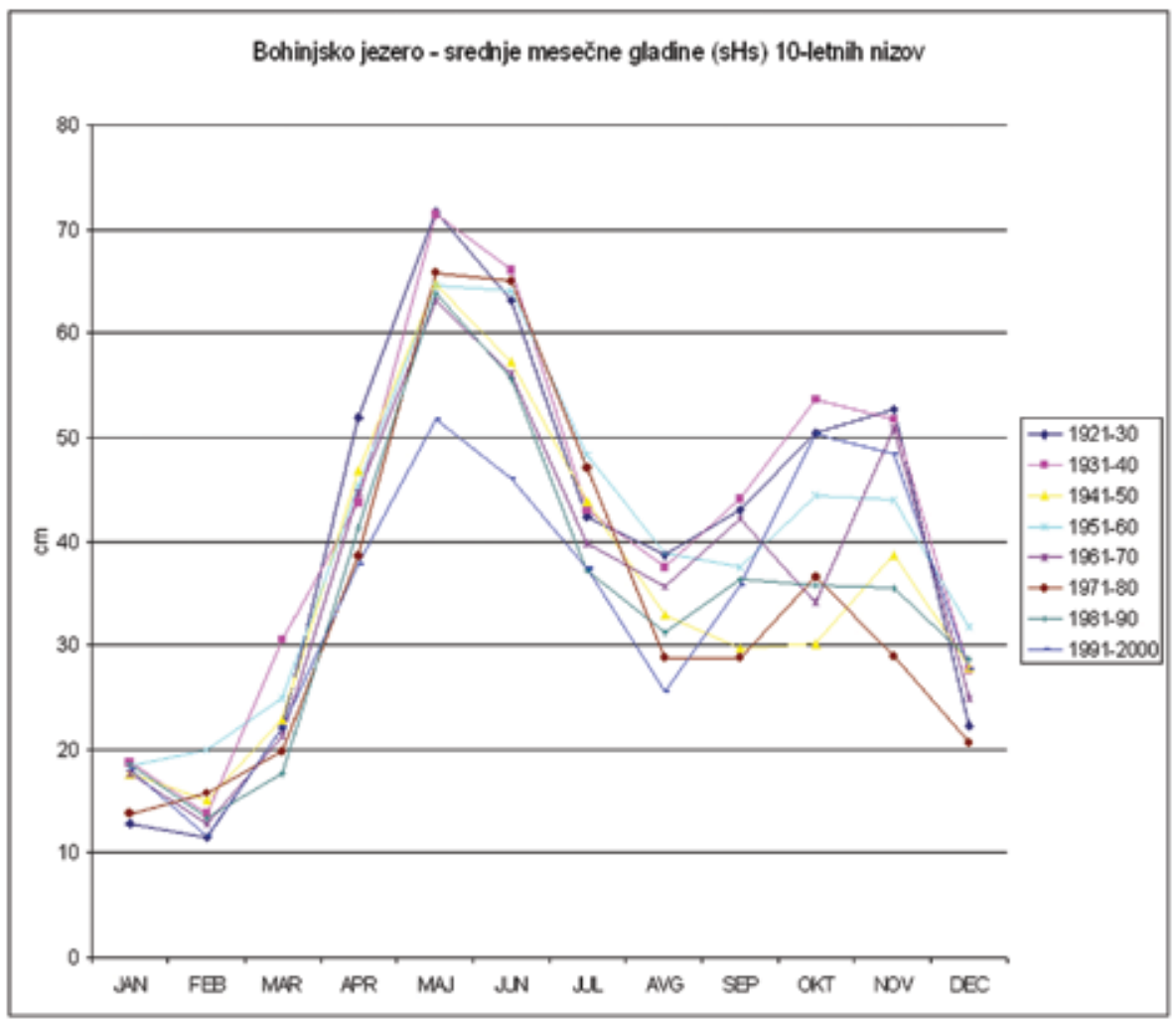

Zelo očitno je, da so poteze režima zelo stabilne pozimi, zlasti januarja in februarja, ko so vodostaji nizki. Srednje mesečne vrednosti desetletnih nizov so raztrosene v intervalu 10 cm (Sliki 3 in 4). Jesenski višek ni tako zanesljiv, srednje mesečne vrednosti nihajo za $25 \mathrm{~cm}$ (Slika 4). Najvišje gladine jezera so praviloma jeseni (Slika 2). Od 36 vodostajev nad $200 \mathrm{~cm}$ jih je bilo kar 28 zabeleženih v oktobru in novembru, od začetka februarja do konca julija pa tako visok vodostaj še ni bil zabeležen. Najvišja gladina, neverjetnih $390 \mathrm{~cm}$ (kota »0« $525.886 \mathrm{~m}+3.9 \mathrm{~m}=529.786 \mathrm{~m}$ n.m.), je bila zabeležena 14. novembra 1969. Najnižja gladina, $-5 \mathrm{~cm}$, je bila izmerjena (po zapisu v temeljni knjigi) v februarju 1929. Pozimi se v času, ko je jezero zaledenelo, večkrat pojavijo negativni vodostaji. Absolutna amplituda jezerske gladine je torej $395 \mathrm{~cm}$.

Pri primerjavi drsečih tridesetletnih nizov je precej očitno zniževanje srednjih mesečnih gladin (Slika 3). Zniževanje gladine Bohinjskega jezera kažejo tudi srednji letni vodostaji (Hs; Slika 5). Trendna črta se leta 1919 začenja pri vodostaju $42 \mathrm{~cm}$, do leta 2004 pa se zniža na $32,5 \mathrm{~cm}$. Ob znižanju gladine za $10 \mathrm{~cm}$ bi se volumen jezera zmanjšal za $330.000 \mathrm{~m}^{3}$ (za $0,3 \%$ ). 
Slika 5: Srednji letni vodostaji (Hs) Bohinjskega jezera od leta 1919 do 2004.

Figure 5: The mean annual water levels (Hs) of Lake Bohinj (from 1919 to 2004).

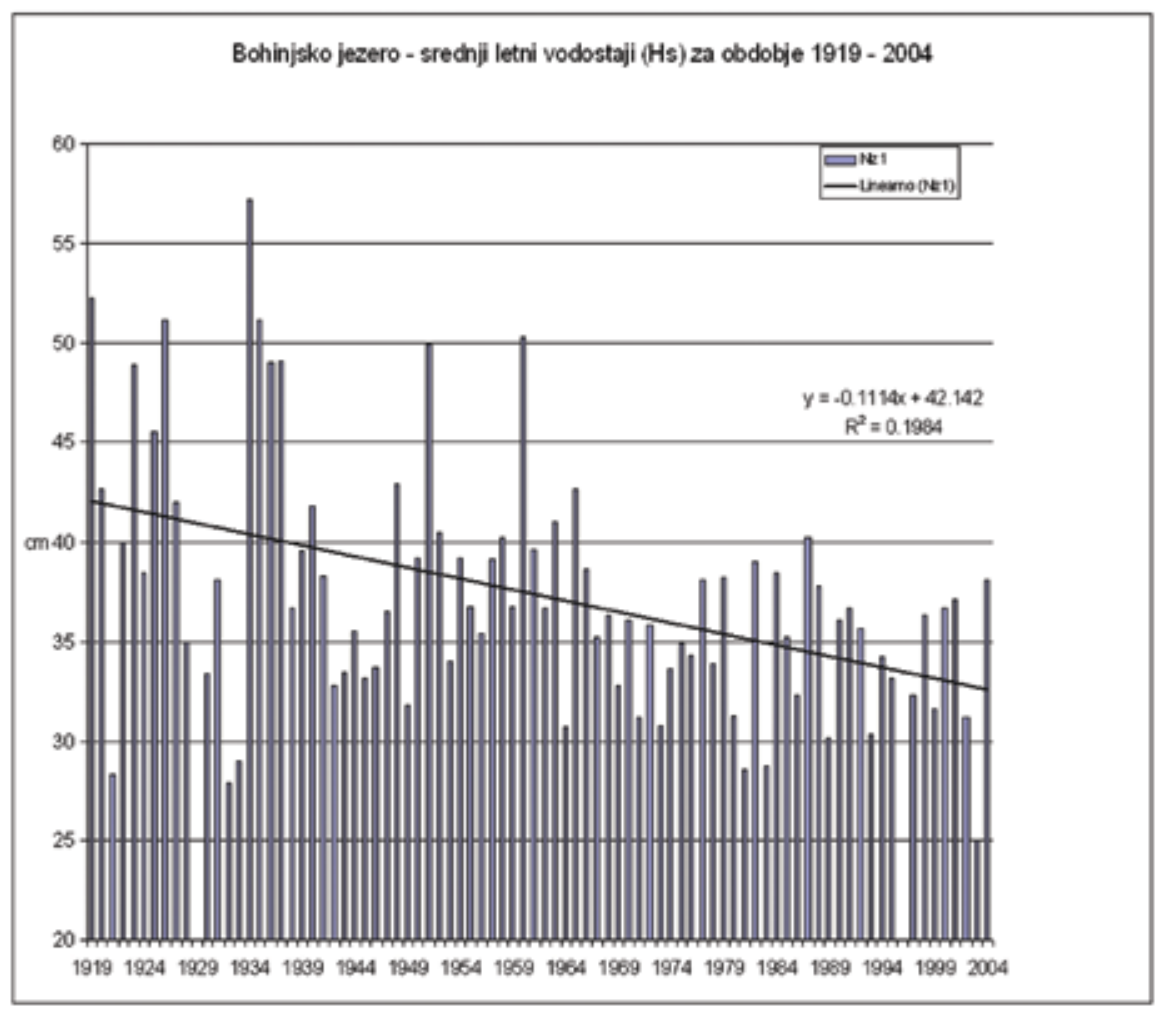

\section{TEMPERATURE VODE IN LED NA JEZERU}

Na območju Bohinja ima vodomerna postaja Ukanc na Savici podatkovni niz temperature vode za obdobje 1951-1968, zadnja leta pa so temperaturo merili le na postaji Sv. Duh na Bohinjskem jezeru. Podatkovni niz sega nazaj do leta 1939 in je bil prekinjen le od 9. januarja do 2. februarja 1997. Dodaten pomen imajo meritve temperature vode $\mathrm{v}$ povezavi z opazovanjem stanja ledu na jezeru. V podatkovni zbirki imamo zaenkrat podatke o ledu od leta 1919. Pripisani so kot oznaka oz. pojasnilo k podatkom o temperaturi in vodostaju.

Temperaturni režim površinskega sloja jezerske vode in spremembe v številu oledenelih dni so bili v literaturi že prikazani (Radinja 1987; Kolbezen 1998; Bat 2004; Frantar 2005). Temperaturni režim z najnižjo srednjo mesečno temperaturo $v$ februarju in najvišjo v avgustu je za jezero z veliko prostornino običajen. Najnižja temperatura, $0{ }^{\circ} \mathrm{C}$, je bila zabeležena $\mathrm{V}$ mesecih od januarja do vključno aprila, najvišja, $24,6{ }^{\circ} \mathrm{C}$, pa je bila izmerjena junija 2003. Srednja letna in vse srednje mesečne temperature obdobja 1939-2005 imajo tendenco naraščanja (Slika 7). 
Slika 6: Povprečne obdobne srednje (sTs), nizke (sHn) in visoke (sTv) mesečne temperature Bohinjskega jezera za obdobje 1939-2004.

Figure 6: The average monthly mean (sTs), low (sHn) and high (sTv) water temperatures of Lake Bohinj for the 1939-2004 period.

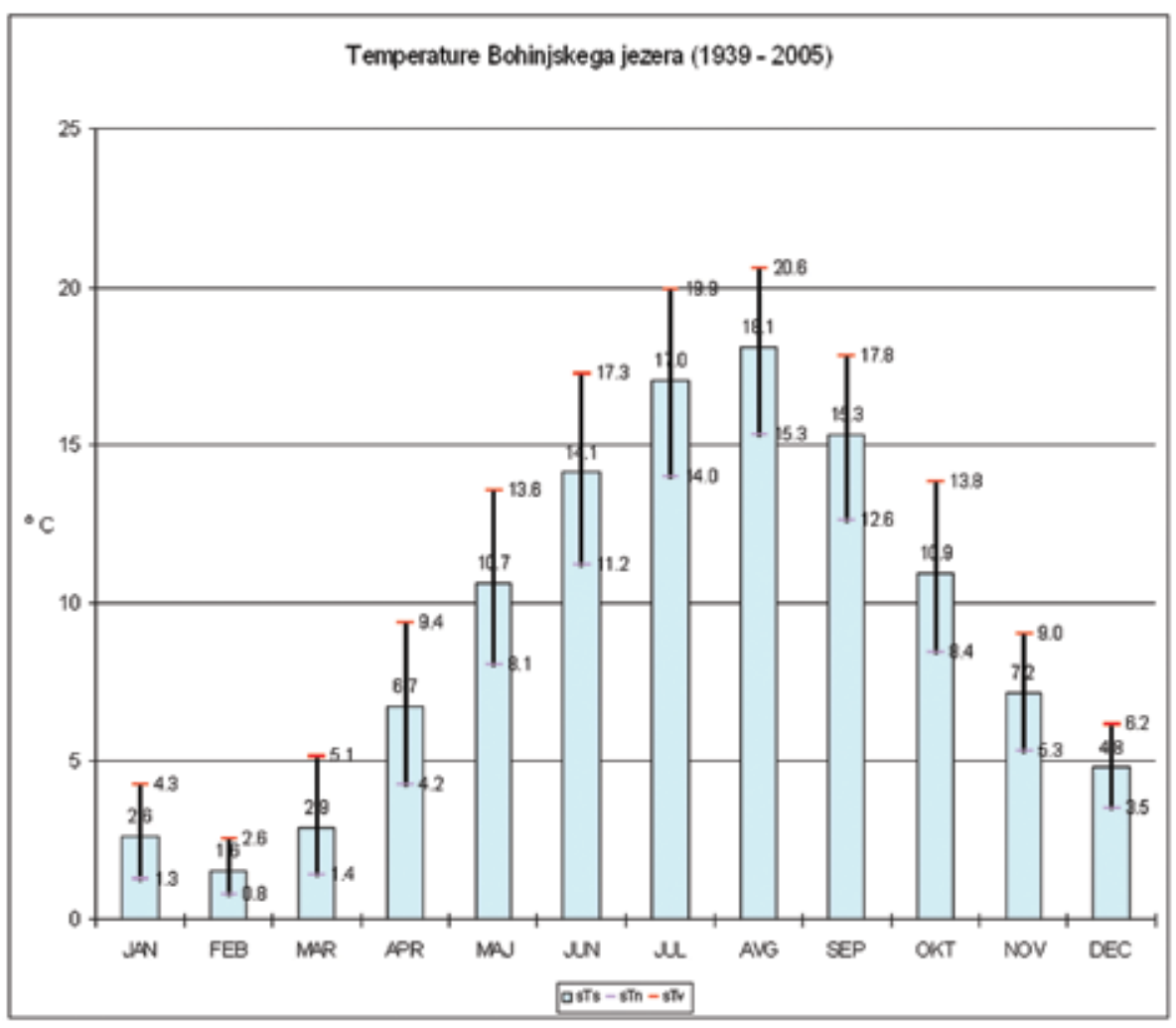

Iz drsečih sredin in primerjave tridesetletnih nizov pa razberemo, da tendenca ni bila stalna. Niz 1951-1980 ima nižje temperature od niza 1941-1970, najvišje temperature pa ima niz 1971-2000. Očitna je tendenca zniževanja nekako do leta 1970, nato je v 70. in 80. letih zanihala, v 90. letih pa temperatura raste. Najbolj naraščajo temperature v avgustu, juniju in juliju, na četrtem mestu pa je že marec. Ti podatki se skladajo z ugotovitvami o oledenitvi jezera (Frantar 2005). Število dni z ledom se manjša. Obdobje 1971-2000 ima 10 oledenelih dni manj od povprečja predhodnih tridesetletnih nizov. Ob koncu 80. in v 90. let 20. stoletja se je povprečno število oledenelih dni še znižalo. Krajšanje gre bolj na račun zgodnejšega taljenja ledu v marcu (18 dni prej glede na obdobje 1961-1990), ki je med meseci z največjim porastom temperature vode, kot kasnejše oledenitve $v$ januarju (6 dni pozneje). Manj od letnega povprečja naraščajo temperature v aprilu, septembru in oktobru. 
Slika 7: Srednje letne temperature Bohinjskega jezera za obdobje 1939-2004.

Figure 7: The mean annual water temperatures of Lake Bohinj (1939-2004).

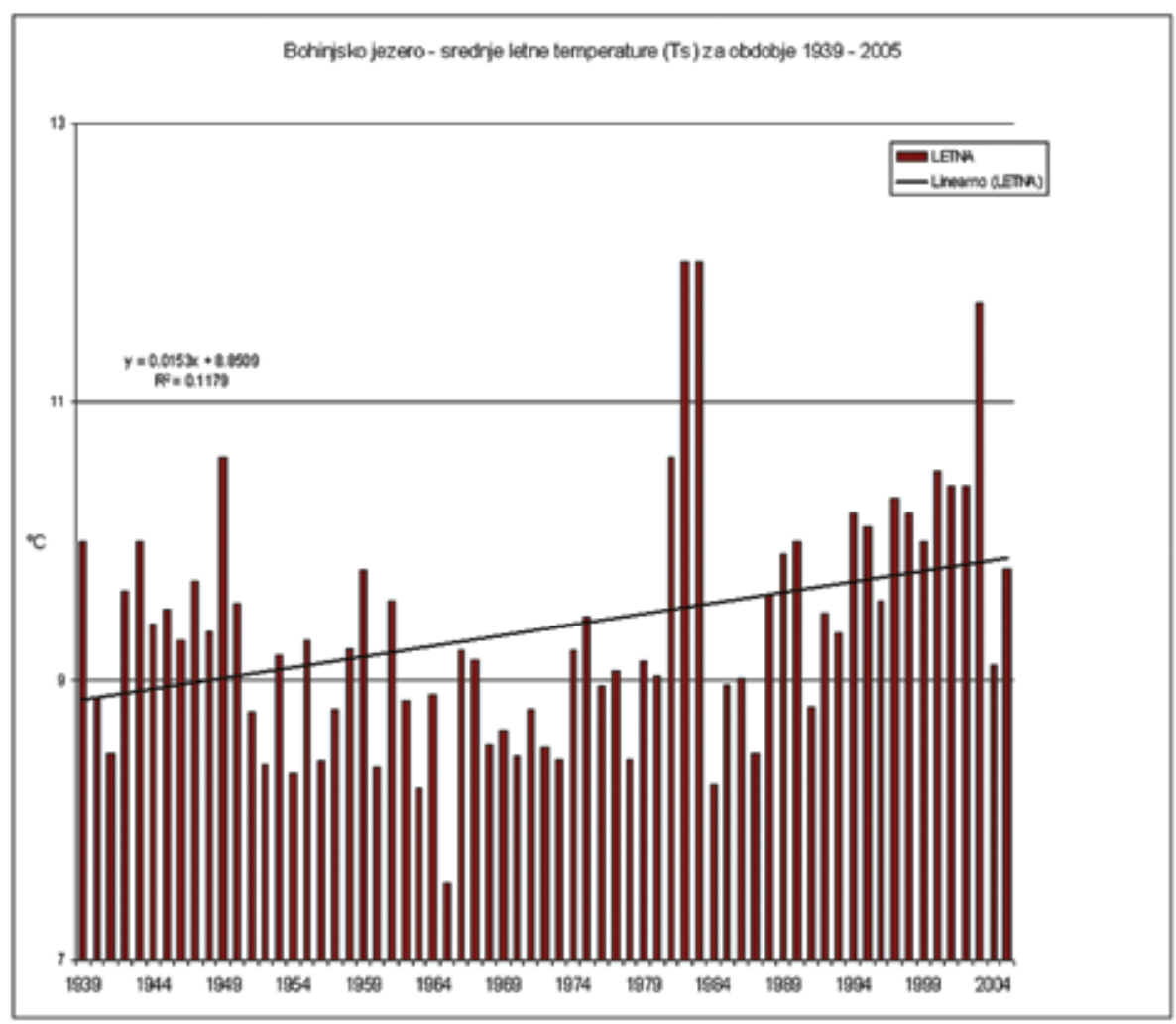

Za temperaturni režim Savice v Ukancu je značilno, da ohranja značilnosti kraškega izvira, ki je tri kilometre gorvodno. Amplituda med srednjo obdobno januarsko in julijsko temperaturo je le $2{ }^{\circ} \mathrm{C}$ (Slika 8). Pri nizu 1951-1968 ni opaziti sezonske zakasnitve na prehodu zime v pomlad. Temperatura je najnižja januarja in potem počasi narašča do julija. Voda se začne ohlajati šele proti koncu septembra. Najvišje in najnižje izmerjene mesečne temperature odstopajo od srednjih največ za $5{ }^{\circ} \mathrm{C}$, pa še to le izjemoma. Savica dovaja v Bohinjsko jezero nekako do aprila vodo, ki je toplejša od vrhnjega sloja, nato pa se vrhnja plast jezera začne hitro segrevati in je toplejša od rečne do decembra. 
Slika 8: Povprečne srednje (sTs), nizke (sHn) in visoke (sTv) mesečne temperature vode Savice na v.p. Ukanc za obdobje 1951-1968.

Figure 8: The average mean (sTs), low (sHn), high (sTv) monthly water temperatures of the Savica at the gauging station Ukanc for the 1951-1968 period.

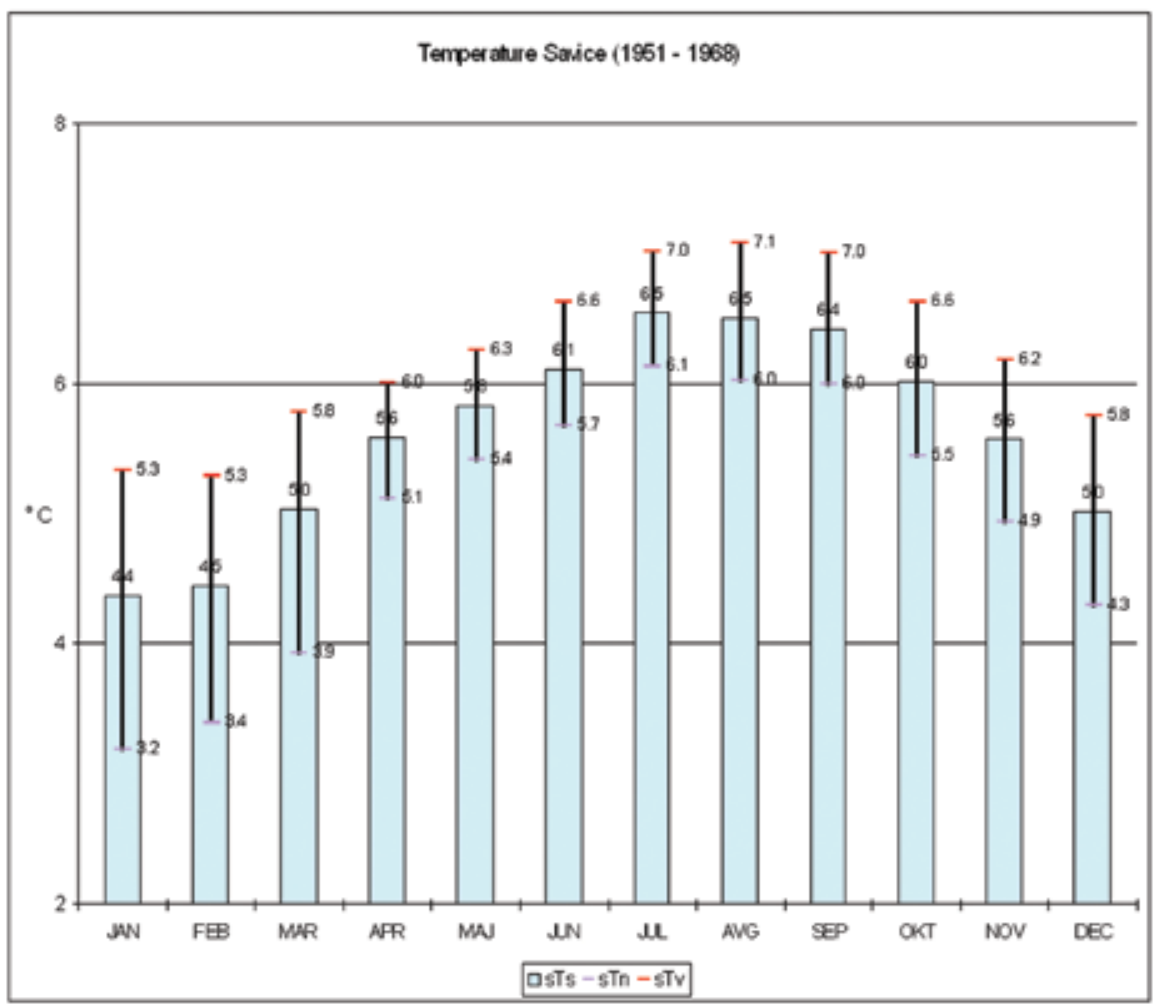

\section{PRETOKI REK, VODNA BILANCA IN SLEDILNI POSKUSI NA OBMOČJU BOHINJA}

Na večini merilnih mest na rekah izvaja ARSO redne hidrometrične meritve, tako da so zanje določeni tudi pretoki. Za območje Bohinja imamo popolna podatkovna niza 1961-2000 za vodomerni postaji Sv. Janez na Savi Bohinjki (niz 1959-2004) in Stara Fužina na Mostnici (1951-2004), za Bohinjsko Bistrico na Bistrici pa imamo niz 1969-2004. Na Savici v Ukancu so bila opazovanja kar dvakrat prekinjena. Podatki so za obdobja 1954-1971, 1984-1989 in 1998-2004. Prekinjena so bila tudi opazovanja v Soteski na Savi Bohinjki, ki ima popoln niz 1951-1989. Upoštevajoč obdobje 1971-2000, imajo vsa merilna mesta alpski snežnodežni pretočni režim (Frantar 2005): prvi višek v maju, sekundarni v oktobru, primarni nižek v februarju in sekundarni v avgustu (Slika 9). Sv. Janez in Soteska na Savi Bohinjki ter Ukanc na Savici se lepo ujemajo. Zelo podobne poteze ima tudi sosednja Radovna v 
Podhomu. Pretočna režima Mostnice v Stari Fužini in Bistrice v Bohinjski Bistrici sta si zelo podobna, od prvih štirih pa se razlikujeta po slabše izraženi snežni retinenci. Ta poteza je lahko posledica manjše nadmorske višine vodozbirnega zaledja, morda tudi drugačnega kraškega pretakanja v zaledju izvirov Bistrice in Mostnice na eni ter Savice na drugi strani. Ukanc in Sv. Janez, slednji na jezernici, imata večjo letno amplitudo.

Radovno smo primerjavi pridali, ker ima v povirju Save zaenkrat najdaljši niz pretokov (1933-2004). Po zapisu v temeljni knjigi naj bi postaja Stara Fužina na Mostnici delovala od leta 1910. Žal so podatki za obdobje pred letom 1950 ohranjeni le v fragmentih in jih bo treba še preveriti. Prav tako tudi podatke za v.p. Soteska za obdobje 1926-1950. Za analizo časovne spremenljivosti pretokov bi bili ti podatki v povezavi z gladinami Bohinjskega jezera zelo dobrodošli. Primerjava razpoložljivih tridesetletnih in desetletnih serij za v.p. Sv. Janez in Stara Fužina kaže na krepitev jesenskega viška. V obdobju 1991-2000 je bil to primarni višek (Slika 10).

Slika 9: Pretočni režimi Save Bohinjke, Savice, Bistrice, Mostnice in Radovne za obdobje 19712000.

Figure 9: The discharge regimes of the rivers Sava Bohinjka, Savica, Bistrica, Mostnica and Radovna for the 1971-2000 period.

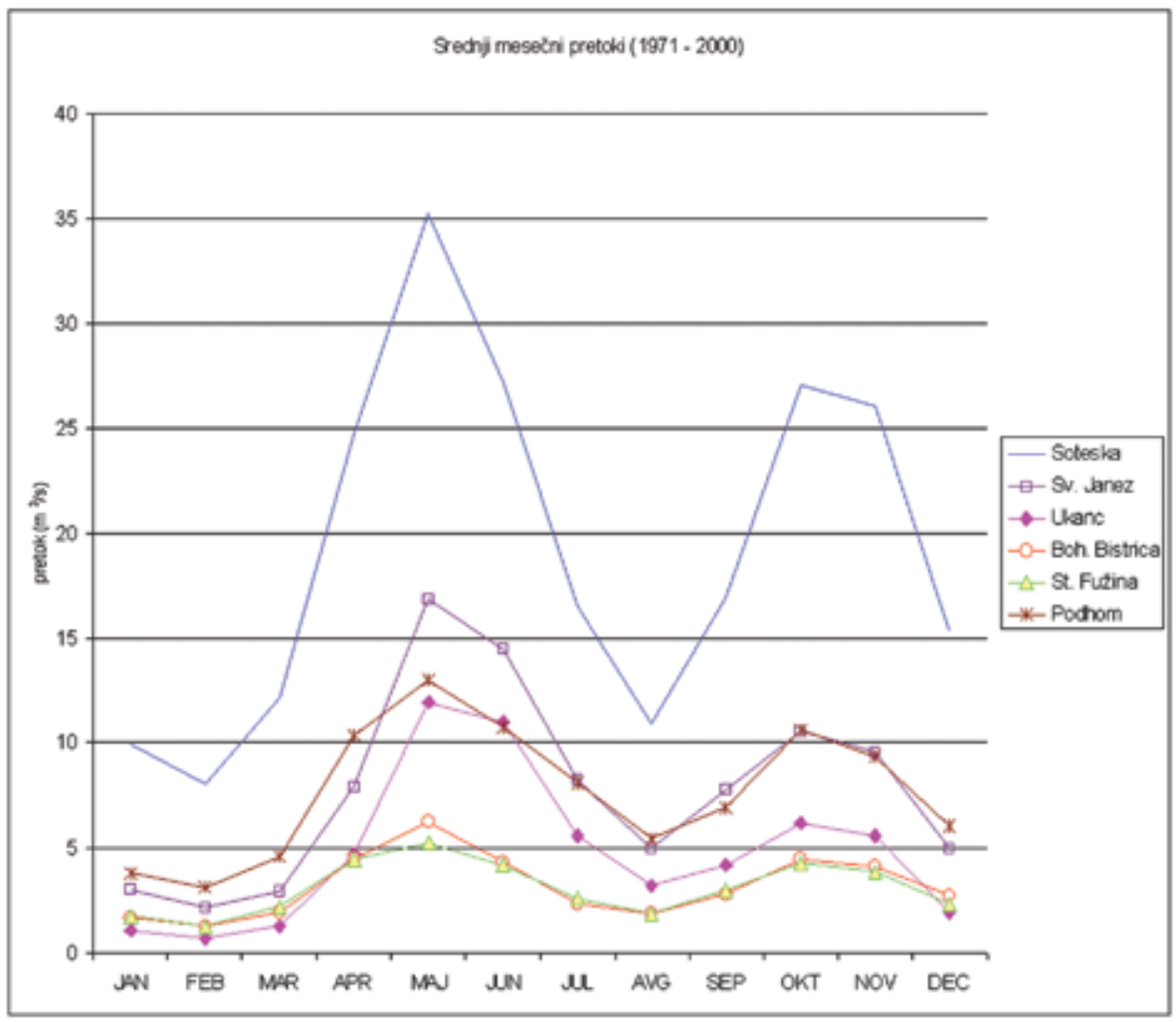


Slika 10: Srednji mesečni pretok Save Bohinjke na v.p. Sv. Janez.

Figure 10: The mean monthly discharges of the Sava Bohinjka at the gauging station Sv. Janez (for ten-year series).

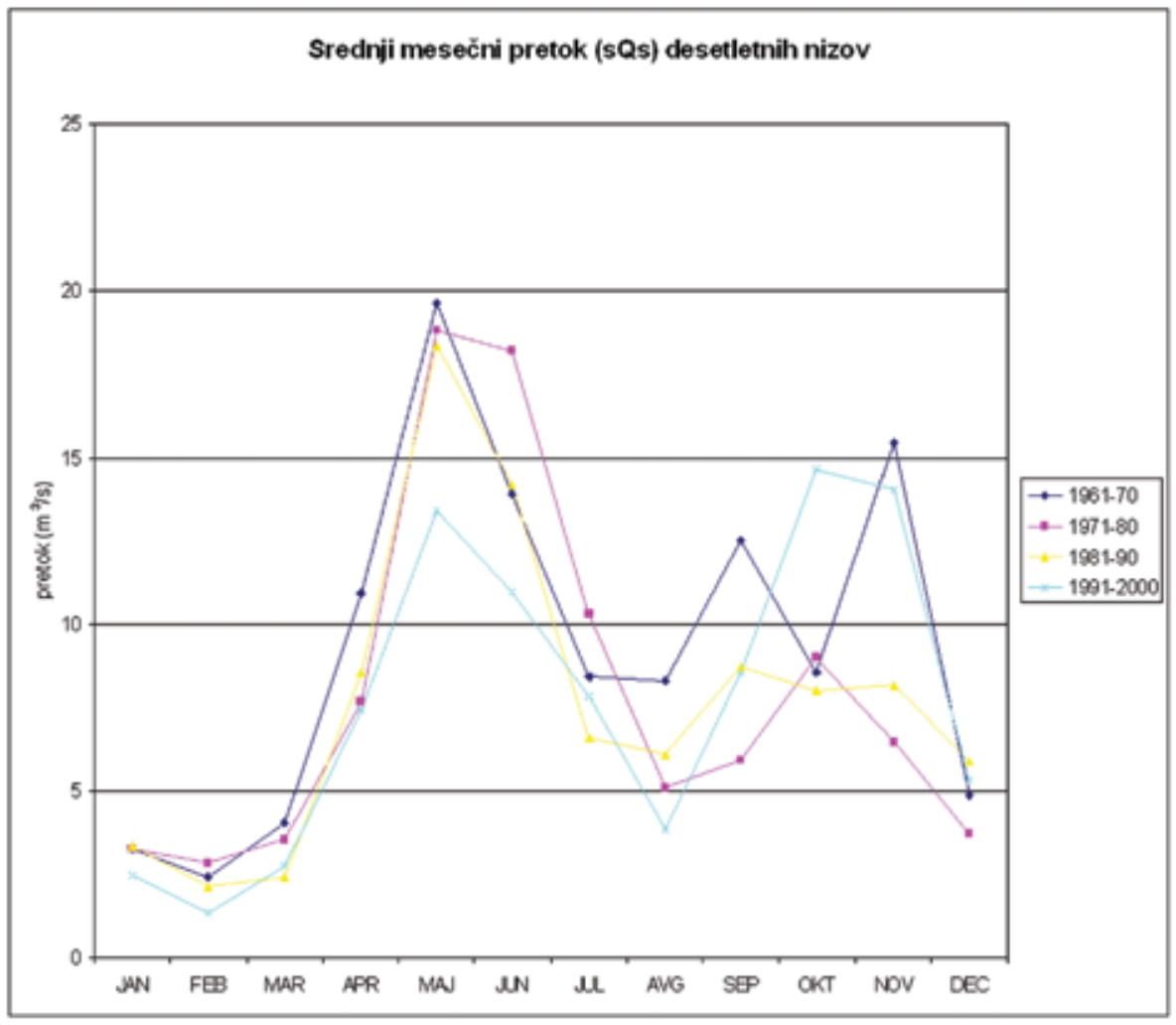

Pretoki se zmanjšujejo, kar kažejo obdobni srednji mesečni in letni pretoki različnih časovnih serij (Sliki 10 in 11). Tudi podrobnejše analize so potrdile statistično značilno tendenco zmanjševanja malih in srednjih pretokov (Uhan in sod. 2006). Lahko bi sklepali, da se gladine in odtok iz Bohinjskega jezera znižujejo vsaj deloma zaradi manjšega dotoka. Kolikšen vpliv ima na to poglabljanje jezernice nismo preverjali, čeprav hranimo na ARSO prečne profile vodomerne postaje Sv. Janez.

V povprečju je v obdobju 1971-2000 iz jezera odtekalo pri Sv. Janezu 7,8 m³/s, srednji letni dotok Savice pa je bil med 4,5 in 5,0 m³/s. Razliko so deloma pokrili površinski dotoki z južnega obrežja jezera, večino pa podvodni kraški izviri ob severni obali jezera.

Za analizo pretočnih režimov na območju Bohinja imamo torej na voljo dovolj podatkov, za analizo časovne spremenljivosti pretokov pa pogrešamo daljše podatkovne nize. Pri usklajevanju členov vodne bilance pa predstavljajo največjo težavo nezanesljive razvodnice. Na neskladja sta opozorili vodnobilančna študija Save Bohinjke (Pristov 1986) ter Vodna bilanca Slovenije za obdobje 1961-1990 (Kolbezen 1998). Seveda je bilo vsaj v krasoslovju 
in hidrogeologiji o podzemnem pretakanju voda na območju Julijskih Alp že pred tem veliko znanega (Gams 1974, 2003; Habič 1989; Novak 1991). Odstopanja dejanskih, hidroloških razvodnic od orografskih so ponekod zelo velika in povsem nedvoumna. Nekaterih v.p. s kakovostnimi podatkovnimi nizi pri usklajevanju členov vodne bilance ne moremo uporabiti kot samostojnih hidrometričnih zaledij, saj jih ne moremo zanesljivo omejiti. Najbolj očiten je primer v.p. Bohinjska Bistrica na Bistrici. Po orografsko določeni razvodnici ima le $13 \mathrm{~km}^{2}$ vodozbirnega zaledja. Glede na povprečne letne padavine in ocenjeno evapotranspiracijo za obdobje 1961-1990 bi pričakovali srednji letni pretok okoli $1 \mathrm{~m}^{3} / \mathrm{s}$ (Kolbezen 1998, 96). Ta pa je bil 3,19 m³ s (sQs za obdobje 1971-2000 je skoraj enak). Rezultat nas sicer ni presenetil, vendar pa je dilema ostala. Hidrološko zaledje mora glede na rezultat obsegati vsaj $40 \mathrm{~km}^{2}$, z razvodnico pa ga nismo znali omejiti. Veliko neskladje med bilančnimi členi je bilo tudi pri Stari Fužini na Mostnici, kjer je odteklo v povprečju 3,28 m³/s, glede na padavine in evapotranspiracijo pa bi pričakovali obdobni srednji pretok (sQs) okoli $5 \mathrm{~m}^{3} / \mathrm{s}$. Pri v.p. Sv. Janez na Bohinjki se je pričakovani pretok sicer precej dobro ujemal z merjenim, vendar pa

Slika 11: Srednji letni pretok Save Bohinjke na v.p. Sveti Janez v obdobju 1959-2004.

Figure 11: The mean annual discharges of the Sava Bohinjka at the gauging station Sveti Janez for the 1959-2004 period.

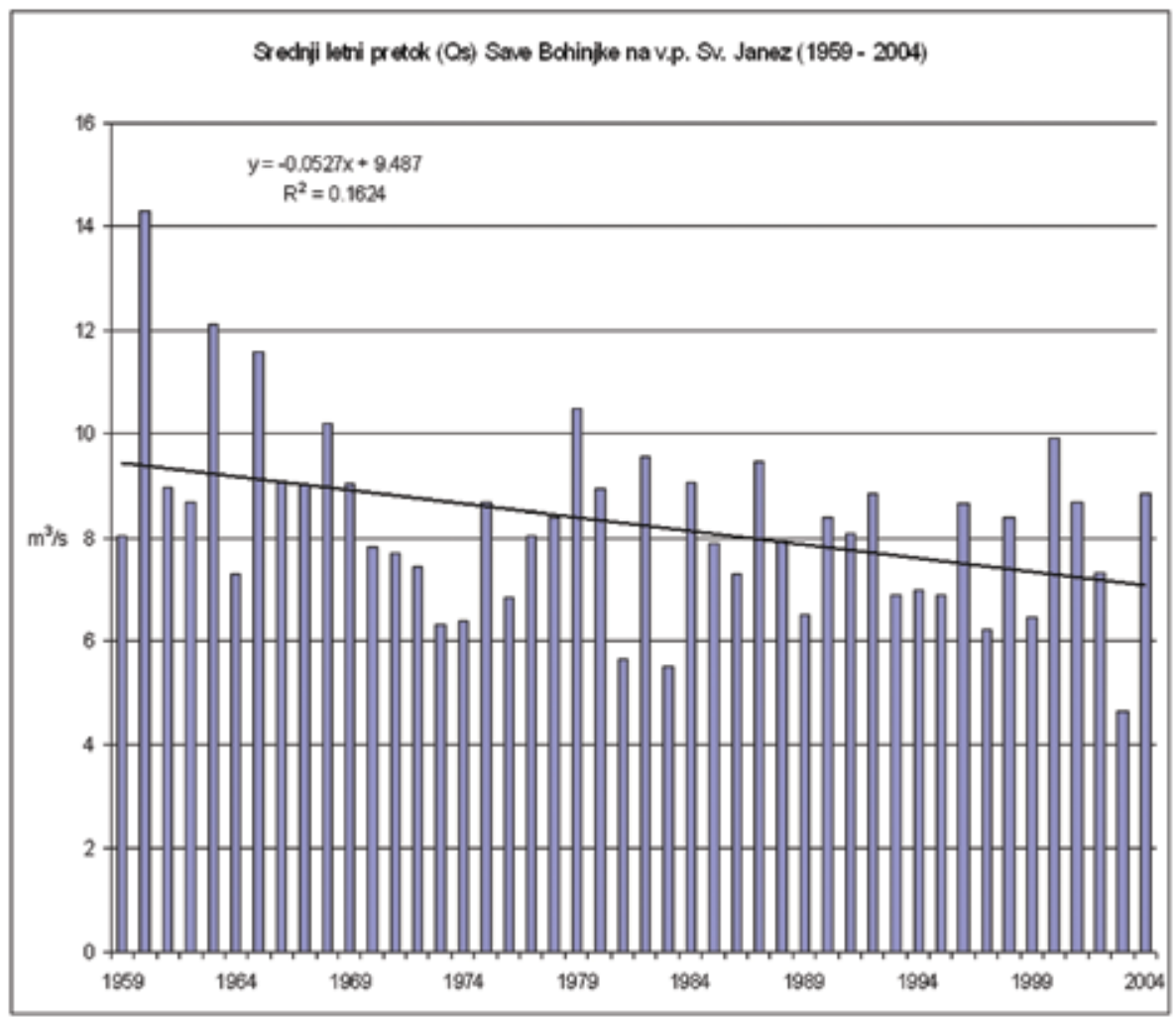


je bil specifični odtok (sQs) glede na sosednja vodozbirna zaledja previsok. Iz zaledja je v povprečju odtekalo okoli $90 \mathrm{l} / \mathrm{s} / \mathrm{km}^{2}$, kar je več kot iz povirja Soče pri Kršovcu, iz zaledja v.p. Stara Fužina pa le dobrih 40 1/s/ $/ \mathrm{km}^{2}$.

Rezultati vodne bilance so v zadnjih desetih letih spodbudili izvedbo dveh sledilnih poskusov. Prvi je bil leta 1996 na Fužinarskih planinah (Trišić 1997), drugi na Voglu leta 2002 (rezultati še niso objavljeni; ustna informacija Niko Trišić in dr. Mišo Andjelov, sek-tor za hidrologijo ARSO). Kot se pogosto zgodi, nam rezultati sledilnih poskusov niso omogočili natančne določitve hidrografskih razvodnic, ampak so dokazali, kar se bilančnega usklajevanja tiče, slabšo možnost - kraško bifurkacijo. Vode s Planine v Lazu odtekajo sočasno proti kraškim izvirom ob in v Bohinjskem jezeru ter proti Mostnici. Tako jih v celoti zajamemo na merilnih mestih Sv. Janez in Stara Fužina skupaj. Sledilo iz vrtine na Voglu pa se je zanesljivo pojavilo v oddaljenem izviru Bistrice. Zaradi sušnega vremena se je sledilo zelo dolgo zadrževalo v podzemlju. $V$ tem času je bilo vzorčenje na jezeru prekinjeno, tako da zveza z vrtino na Voglu ni izključena.

Slika 12: Sledilni poskusi v povirju Save Bohinjke (Habič 1989; Novak 1991; Trišić 1997). Označeni sta tudi mesti, kjer je bilo vlito sledilo ob sledilnem poskusu na Voglu.

Figure 12: Water tracing tests in the headwaters of the Sava Bohinjka (Habic 1989; Novak 1991; Trišic 1997). Marked are also the two points where the tracer was applied in the tracing test on the plateau Vogel (\%).

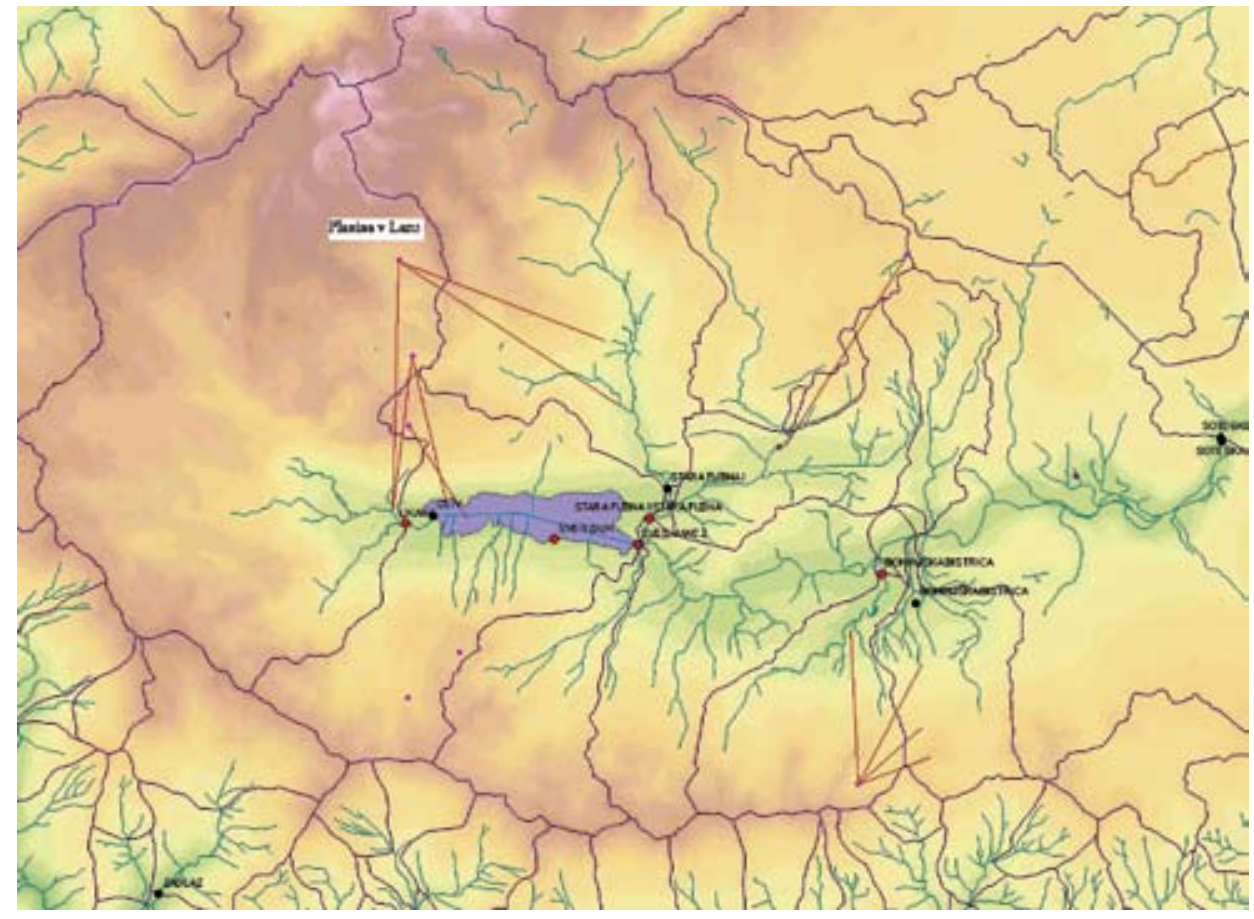


To pa pomeni, da vodno bilančno območje Bohinja najbolj zadovoljivo pokrije prav v.p. Soteska, na kateri so bila opazovanja žal leta 1989 prekinjena. V povprečju prejme po rezultatih vodne bilance 1971-2000 (Frantar in drugi 2006) vodozbirno zaledje v.p. Soteska letno $2760 \mathrm{~mm}$ padavin, kar ustreza pretoku $26,8 \mathrm{~m}^{3} / \mathrm{s}$. Letno se za evapotranspiracijo porabi $670 \mathrm{~mm}$ padavin, kar bi zmanjšalo pretok za $6,5 \mathrm{~m}^{3} / \mathrm{s}$ na $20,3 \mathrm{~m}^{3} / \mathrm{s}$. Ocenjujemo pa, da pri Soteski dejansko odteče 19,6 m³/s, kar je enako $2020 \mathrm{~mm}$ padavin. Odtočni količnik je torej med 0,73 in 0,76 , specifični odtok pa je okoli $65 \mathrm{l} / \mathrm{s} / \mathrm{km}^{2}$. Nekaj večji so specifični odtoki le v porečju Tolminke in Soče nad Kobaridom.

\section{SKLEP}

Dež 'ima v Bohinju mlade', hkrati pa se proti njemu podzemno in površinsko stekajo vode $\mathrm{z}$ obsežnega zaledja, ki spada med najbolj namočena področja v Sloveniji. Posledica velike količine padavin in podpovprečne evapotranspiracije je nadpovprečno visok odtok vode. Vodozbirno zaledje Save pri Soteski obsega 1,5 \% ozemlja Slovenije, k odtoku vode $\mathrm{z}$ ozemlja države pa prispeva kar $4 \%$. Večina zaledja je skoraj neposeljena in v okviru Triglavskega narodnega parka še dodatno zaščitena pred človekovimi posegi v okolje. Vsekakor vode kot pokrajinotvornega dejavnika v Bohinju res ne moremo spregledati.

\section{Viri in literatura}

Arhiv in podatkovne baze sektorja za hidrologijo ARSO (julij, 2007).

Bat, M., Remec - Rekar, Š. 2003. Jezera. Vodno bogastvo Slovenije. Ljubljana.

Bat, M., Uhan, J. 2004. Vode. Narava Slovenije. Ljubljana.

Gams, I. 1974. Kras. Zgodovinski, naravoslovni in geografski oris. Ljubljana.

Gams, I. 2003. Kras v Sloveniji v prostoru in času. Ljubljana.

Habič, P. 1989. Sledenje kraških voda v Sloveniji. Geografski vestnik, 61, 3-20. Ljubljana.

Hrvatin, M. 1998. Pretočni režimi v Sloveniji. Geografski zbornik, 38, 59-87. Ljubljana.

Frantar, P., Hrvatin, M. 2005. Pretočni režimi v Sloveniji med letoma 1971 in 2000. Geografski vestnik, 77-2, 115-127. Ljubljana.

Frantar, P. 2003. Pretočni režimi na reki Savi in njihove spremembe med obdobjem 19611990 in 1991-2000. 14. Mišičev vodarski dan. Maribor.

Frantar, P., Uhan, J. 2005. Vse manj ledu tudi na Bohinjskem jezeru. Medmrežje: http://www. arso.gov.si/vode/publikacije (julij 2007).

Frantar, P., Dolinar, M., Kurnik, B., Ovsenik Jeglič, T., Bartalanič, R., Hrvatin, M., Jerovšek, J., 2006. Poročilo o rezultatih projekta vodna bilanca Slovenije za obdobje 1971-2000. Arhiv sektorja za hidrologijo ARSO. Ljubljana.

Kolbezen, M., Pristov, J. 1998. Površinski vodotoki in vodna bilanca Slovenije. Ljubljana.

Kolbezen, M. 1998. Jezera. V: Geografija Slovenije. Ljubljana.

Novak, D. 1991. Novejša sledenja kraških voda v Sloveniji po letu 1965. Geologija, 33, 461478. Ljubljana.

Pristov, J. 1986. Hidrometeorološka študija Save Bohinjke.Vodna bilanca I in II. Elaborat, Arhiv sektorja za hidrologijo ARSO. Ljubljana. 
Radinja, D. 1987. Bohinjsko jezero. V: Enciklopedija Slovenije, 1. Ljubljana.

Trišić, N., Bat, M., Polajnar, J., Pristov, J. 1997. Water balance investigations in the Bohinj region. Tracer Hydrology. Rotterdam.

Uhan, J., Ulaga, F., Frantar P., Sušnik, M. 2006. Trends of the annual mean river discharges in Slovenia. XXIII Conference of the Danubian countries on the Hydrological Forecasting and Hydrological Bases of water management. Belgrade.

\section{HYDROLOGICAL INVESTIGATIONS OF THE ENVIRONMENTAL AGENCY OF THE REPUBLIC OF SLOVENIA IN THE BOHINJ REGION}

\section{Summary}

\section{Introduction}

The Environmental Agency of the Republic of Slovenia performs hydrological measurements in the Bohinj region at the following water gauging stations: Sveti Janez on the Sava Bohinjka, Ukanc on the Savica, Bohinjska Bistrica on the Bistrica, Stara Fužina II on the Mostnica, and Sveti Duh on Lake Bohinj. The majority of data on water levels, temperatures and discharges, hydrometric measurements and rating curves from the active and the abandoned gauging stations are stored in the digital database and they are available to public. The oldest series of data dates from the early $20^{\text {th }}$ century (Tables 1,2 ; Fig. 1).

\section{Water levels}

The data on water levels are of great importance especially for lakes. The series of data from the gauging station Sveti Duh on Lake Bohinj started in 1919. The only missing data are the daily data for 1929, and for three months in the year 1996. The annual water level regimes for the period of over thirty years were published by Radinja (1987) and Bat (2003), and they are very similar to the alpine nival-pluvial discharge regime (Frantar 2005). Obviously, the regime is very stable in winter when the water levels are low (Fig. 2). Less reliable are the high levels in autumn. Thus 28 water levels above $220 \mathrm{~cm}$ of the total 36 were registered in October or November, and none was registered from February to August. The highest level was recorded on 14 November 1969, and was $390 \mathrm{~cm}$ above the gauge datum. The trend line of the mean annual levels declines (Fig. 5). A comparison of monthly averages by decades for the whole period (1919-2004) shows that some changes took place. In the 1991-2000 decade the spring and the autumn water level maximums are, for the first time, the same (Fig. 3 and 4).

\section{Water temperatures and ice}

At the gauging station Sveti Duh on Lake Bohinj temperature observation has been done since 1939 (Fig. 6), while the data on ice cover are combined with the data on water level. The temperature regime of the lake and the changing number of days with ice cover were published by Radinja (1987), Kolbezen (1998), Bat (2004) and Frantar (2005).

The trend line of the annual and the monthly mean water temperatures in the 19392005 period rises, though the temperatures kept decreasing until the year 1970. Evident in the 
last decade is the rising trend (Fig. 7). The most obvious is the rising of water temperature in summer months and in March. The number of days with ice cover declines (Frantar 2005). In the 1971-2000 period the ice cover remained for ten days less than the average amounts were for the series of the previous thirty years. In the last decade, the March melting began 18 days earlier than the average is for the 1961-90 period. The January freezing of the lake is delayed for 6 days.

Water temperatures at the Ukanc gauging station on the Savica were recorded from 1951 to 1968 (Fig. 8). The temperature regime of the river is that of a karstic spring. The annual amplitude of monthly mean temperatures between the warmest and the coldest months is $2{ }^{\circ} \mathrm{C}$. From December through March the river supplies warmer water to the lake than to its surface layer.

\section{River discharges, water balance and water tracing experiments in the Bohinj region}

All the gauging stations in the Bohinj region have, according to the data of regular hydrometric measurements, rating curves and water level/discharge transformations, the alpine nival-pluvial discharge regime (1971-2000 period; Frantar 2005). The primary maximum occurs in May, the secondary in October, and the primary minimum occurs in February and the secondary in August (Fig. 9). The autumn maximum is even more significant and in the 1991-2000 period, it already turned into the primary maximum (Fig. 10). The average annual and monthly mean discharges of different time series indicate the decline in water quantities (Fig. 10 and 11).

In the 1971-2000 period, the average measured inflow into Lake Bohinj by the Savica amounted to $4.5 \mathrm{~m}^{3} / \mathrm{sec}$, and the outflow at the gauging station Sveti Janez on the Sava Bohinjka amounted to $7.8 \mathrm{~m}^{3} / \mathrm{sec}$. The difference is mainly due to the inflow of karstic springs that mostly spring from under the surface of the lake along its northern shore. The karstic drainage represents the basic problem for establishing the water balance of the Bohinj region.

The tracing tests made on two karstic plateaus, the Fužinarske planine (Trišić at all 1997) and the Vogel (2002; verbal communication), confirmed the existence of vast karstic bifurcation areas (Fig. 12). Waters from the Planina v Lazu simultaneously drain to the karstic springs in Lake Bohinj and to the Mostnica River. The tracer from the plateau Vogel emerged in the distant karstic spring of the Bistrica.

Besides being anticipated by the karstic and hydro-geological studies, the karstic bifurcations were also anticipated by the hydrological measurements. The gauging station Soteska on the Sava Bohinjka is the most appropriate for the harmonization of data on water balance as regards the karstic drainage. The average precipitation in the drainage area of the gauging station Soteska for the 1971-2000 period amounts to $2760 \mathrm{~mm}$ annually or the discharge of $26.8 \mathrm{~m}^{3} / \mathrm{sec}$, and $670 \mathrm{~mm}$ of precipitation (or $6.5 \mathrm{~m}^{3} / \mathrm{sec}$ ) evaporate (Frantar 2007). Accordingly, $2090 \mathrm{~mm}$ or $20.3 \mathrm{~m}^{3} / \mathrm{sec}$ of water, on the average, runs off from the drainage basin. In accordance with the measurements at the gauging station Soteska, 2020 $\mathrm{mm}$ or $19.6 \mathrm{~m}^{3} / \mathrm{sec}$ of water runs off, which corresponds to the runoff coefficient 0.73 or the specific runoff about $65 \mathrm{l} / \mathrm{sec} / \mathrm{km}^{2}$. Higher values were established only in some sections of the Soča catchment area. 